\title{
MASTER
}

\section{CARRY-OVER GRAIN STOCKS AS AN EMERGENCY FUEL}

\author{
H. Davitian and H. SerRy
}

August 1979

Prepared for the

POWER SYSTEMS DIVISION

UNITED STATES DEPARTMENT OF ENERGY

TECHNOLOGY ASSESSMENT GROUP

DEPARTMENT OF ENERGY AND ENVIRONMENT

BROOKHAVEN NATIONAL LABORATORY ASSOCIATED UNIVERSITIES, INC.

UNDER CONTRACT NO, EY-76-C-02-0016 WITH THE

UNITED STATES DEPARTMENT OF ENERGY 


\section{DISCLAIMER}

This report was prepared as an account of work sponsored by an agency of the United States Government. Neither the United States Government nor any agency Thereof, nor any of their employees, makes any warranty, express or implied, or assumes any legal liability or responsibility for the accuracy, completeness, or usefulness of any information, apparatus, product, or process disclosed, or represents that its use would not infringe privately owned rights. Reference herein to any specific commercial product, process, or service by trade name, trademark, manufacturer, or otherwise does not necessarily constitute or imply its endorsement, recommendation, or favoring by the United States Government or any agency thereof. The views and opinions of authors expressed herein do not necessarily state or reflect those of the United States Government or any agency thereof. 


\section{DISCLAIMER}

Portions of this document may be illegible in electronic image products. Images are produced from the best available original document. 
BNL 51050

UC-61

(Fuels from Biomass Systems -

TID-4500)

\section{CARRY - OVER GRAIN STOCKS AS AN EMERGENCY FUEL}

H. Davitian and H. SerRy

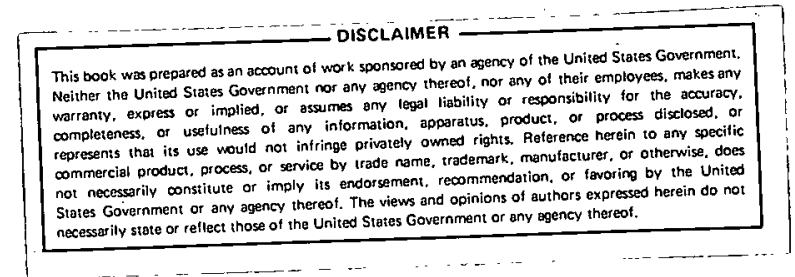

August 1979

Prepared for the

POWER SYSTEMS DIVISION

UNITED STATES DEPARTMENT OF ENERGY

TECHNOLOGY ASSESSMENT GROUP DEPARTMENT OF ENERGY AND ENVIRONMENT

\section{BROOKHAVEN NATIONAL LABORATORY \\ UPTON, NEW YORK 11973}


NOTICE

This report was prepared as an account of work sponsored by the. United States Government. Neither the United States nor the United States Department of Energy (DOE), nor any of their employees, nur any of their cuntracturs, subcunteacius, un their employees, makes any warranty, express or implied, or assumes any legal liability or responsibility for the accuracy, completeness or usefulness of any information, apparatus, product or process disclosed, or represents that its use would not infringe privately owned rights.

Printed in the United States of America Available from

National Technical Information Service

U.S. Department of Commerce

5285 Port Royal Road Springfield, VA 22161

Price: Printed Copy $\$ 4.00$; Microfiche $\$ 4.00$ 
In a typical year, the U.S. has carry-over stocks of grain with a total energy content of 0.5 to 1.0 quad ( $10^{15}$ Btu). These stocks could serve as an emergency supply of solid fuel which could provide a partial substitute for coal in coal power plants. This report discusses the technical feasibility of burning grain-coal mixtures, the availability and price of carry-over stocks, and the amount of coal for which the grain could substitute.

\section{ACKNOWLEDGMENTS}

The authors wish to thank Kaye Van Valkenberg for assistance in the editing of this manuscript. Thanks are also due to Susan White DePace and to Gwen Weaver who bore the burden of preparing numerous drafts with patience and good humor.

This study was supported by the Power Systems Division of the United States Department of Energy under contract No. EY-76-C-02-0016. 
THIS PAGE

\section{WAS INTENTIONALLY \\ LEFT BLANK}


CONTENTS

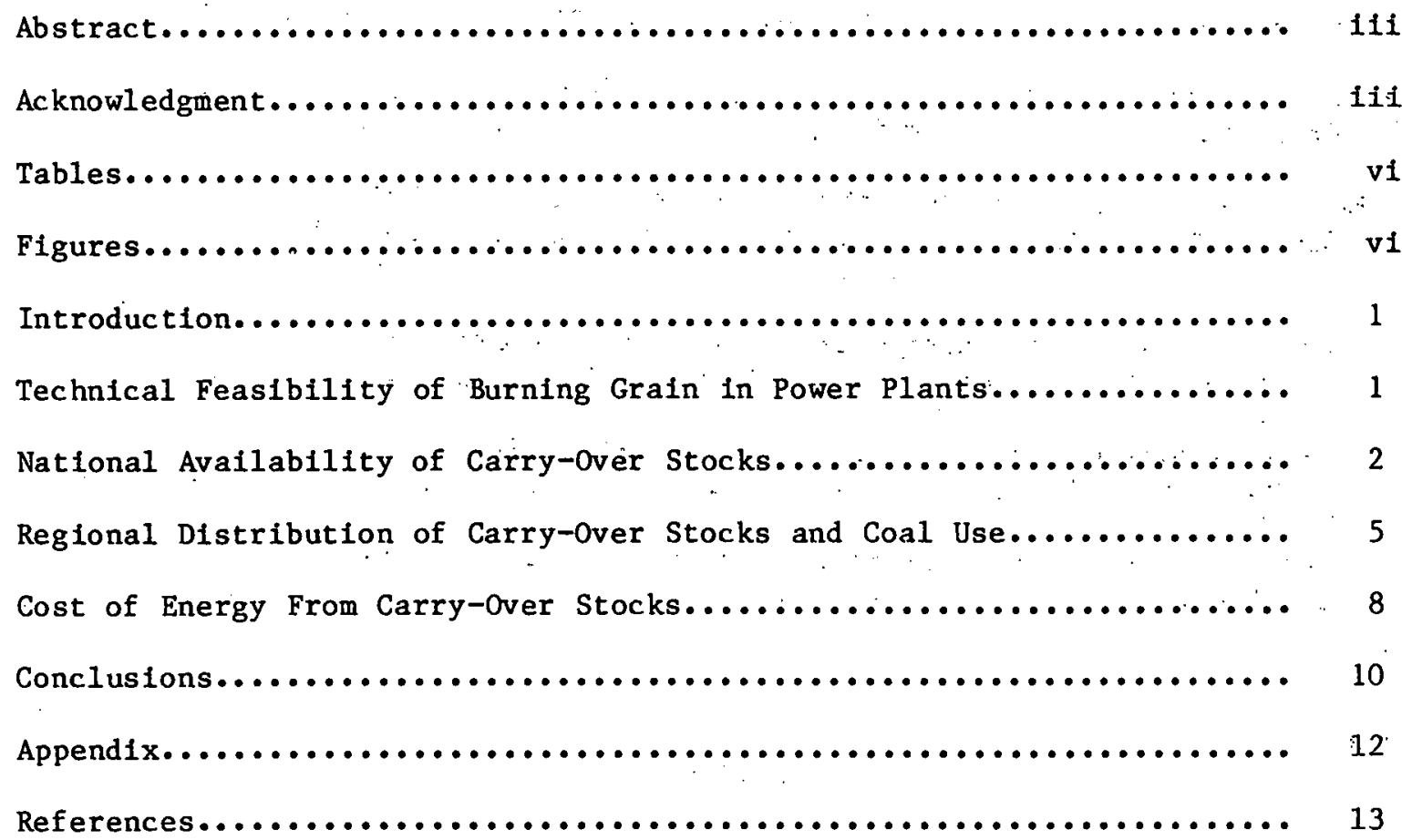




\section{TABLES}

1 . Energy Content of Surplus U.S. Grain Stocks ( $10^{15}$ Btu/year)......

2 Coal Displacement Potential of Carry-Over Stocks in Major

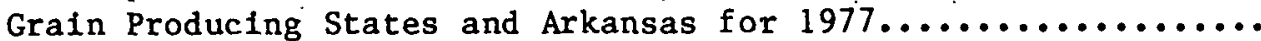

3 Potential Use of Carry-Over Stocks in Extended Grain Belt Region During Coal Shortages of Various Severities (Based

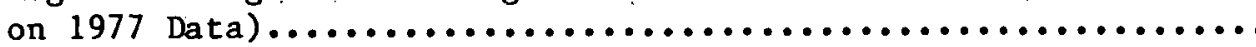

4 Cost of Transporting Carry-Over Stocks from Elevators to Coal Power Plants Using: 1979 Illinols Railroad Rates.......... 9

5 Estimated Average Delivered Cost of Carry-Over Stocks to Nearest Coal Power Plants...........................

6 Season Average Price Received by Farmers for Corn, Soybean,

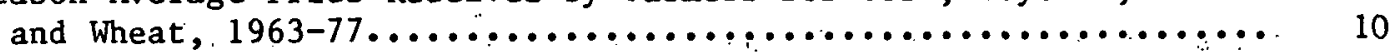

FIGURES

1 Energy Content of Carry-Over Grain Stocks United States,

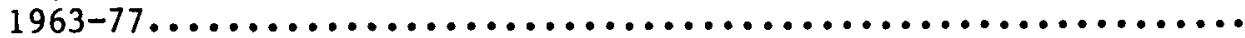

2 Energy Content of the Total U.S. Production of Corn, Soybeans,

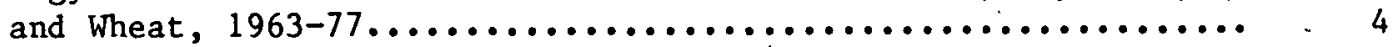




\section{INTKODUCTION}

This paper reports on the feasibility of using carry-over grain stocks to supplement or replace coal used for electric power generation during emergency fuel shortages. Coal plants generally do not have multifuel capabilities enabling them to use liquid or gaseous fuel substitutes when coal is not available. Current practice during coal shortages is to rely primarily upon increased electricity generation from those nuclear or oil-burning plants which would otherwise be operating below capacity. In general, excess capacity is limited and electricity from such plants is expensive. Carry-over grain stocks are the only major source of solid fuel that are stockpiled and can be substituted for coal in coal-burning plants. Hence, they could potentially serve as an alternative emergency supply.

This study examines the technical feasibility of burning grain-coal mixtures, the availability and price of carry-over stocks, and the amount of coal that could be displaced by the stocks. Only those energy emergencies resulting from reduced coal supplies have been considered; although shortages of other fuels could place added pressure on coal markets and create a short term imbalance in the coal supply-demand picture, such shortages are not considered in this study.

\section{TECHNICAL FEASIBILITY OF BURNING GRAIN IN POWER PLANTS}

The feasibility of substituting grain for coal in power plants has been demonstrated in a project conducted by the Electric Department in Logansport, Indiana. Seed corn which is too old for commercial use is purchased at an equivalent cost of $\$ 0.44 / 10^{6}$ Btu. A grain and coal mixture consisting of $20 \%$ grain by weight is fed into a $39 \mathrm{MW}$ plant (derated to $23 \mathrm{MW}$ for control of particulate emissions). 1 The grain and coal are crushed together into $11 / 2$ inch lumps, requiring no modification of crushing or feeding equipment. Since corn has only about $70 \%$ of the heating value of the coal used in the Logansport plant, mixing the two requires about $7 \%$ more fuel by weight to produce the same output of electricity than is needed with coal alone. No major problems have been encountered in operating the plant with this mixture, and it produces less environmental pollution than coal alone. 1

The coal preparation and feeding system employed by a power plant is likely to be the primary factor governing the feasibility of burning grain. A crusher as used in the Logansport plant can accept a grain/coal mixture, whereas it is questionable whether a pulverizer, which is now more commonly used, could properly feed the mixturc. Since there appears to have been little research in this area except for the Logansport Electric Department's project, it is not knnwn whether minor modifications would permit the pulverizer units to burn grain-coal mixtures.

The combustion characteristics of grain/coal mixtures with ratios higher than $1: 4$ have not been explored, and hence it is not known whether higher graln to coal feed ratios are acceptable. If it proves necessary to mix grain with coal to achieve acceptable combustion properties, the amount of grain that 
could be used in an emergency would be limited by the stocks of coal available. For instance, coal power plants typically have a 90 day stockpile of coal at the plant; if supplemented with grain at a 1:4 ratio during an emergency, this supply could be extended to 104 days, at most, no matter how much grain was available. If higher grain to coal ratios prove feasible, coal supplies could be extended much further. Because of the lack of knowledge regarding technically acceptable coal-gain.ratio, it is assumed in the remainder of his report that there are no constaints in the mixture ratio.

Transportation of grain to the plants should not be a major problem since both grain elevators and coal plants are usually located adjacent to railroads.

\section{NATIONAL AVAILABILITY OF CARRY-OVER STOCKS}

Carry-over stocks* are defined as the quantity of grain in storage as of the end of the marketing year, and serve as a convenient measure of the amount of grain available during an emergency. Historical data on carry-over stocks of corn, soybeans and wheat were analyzed to provide a rough picture of the quantity and regional distribution of carry-over stocks. These three grains comprise about $78 \%$ of the major grain and oil seed crops in the United States. The average energy. content of the carry-over stocks for the eight years 1970-1977 is 0.32 quad for corn, 0.32 quad for wheat, and 0.16 quad for soybeans, totaling about 0.8 quad. $^{+}$However, there are substantial variations in the stocks even on a year-to-year basis (see Table 1 and Fig. 1); over the 15 year period 1963-77, the stocks for the three grains varied from a low of 0.42 quad in 1974 to a high of 1.28 quad in 1972. In the three years 1975-1977 alone, the quantity of carry-over stocks varied between 0.42 and 0.99 quad. Although production of these grains has increased significantly since 1963 (see Fig. 2), the general trend has been a reduction in the stocks as agricultural

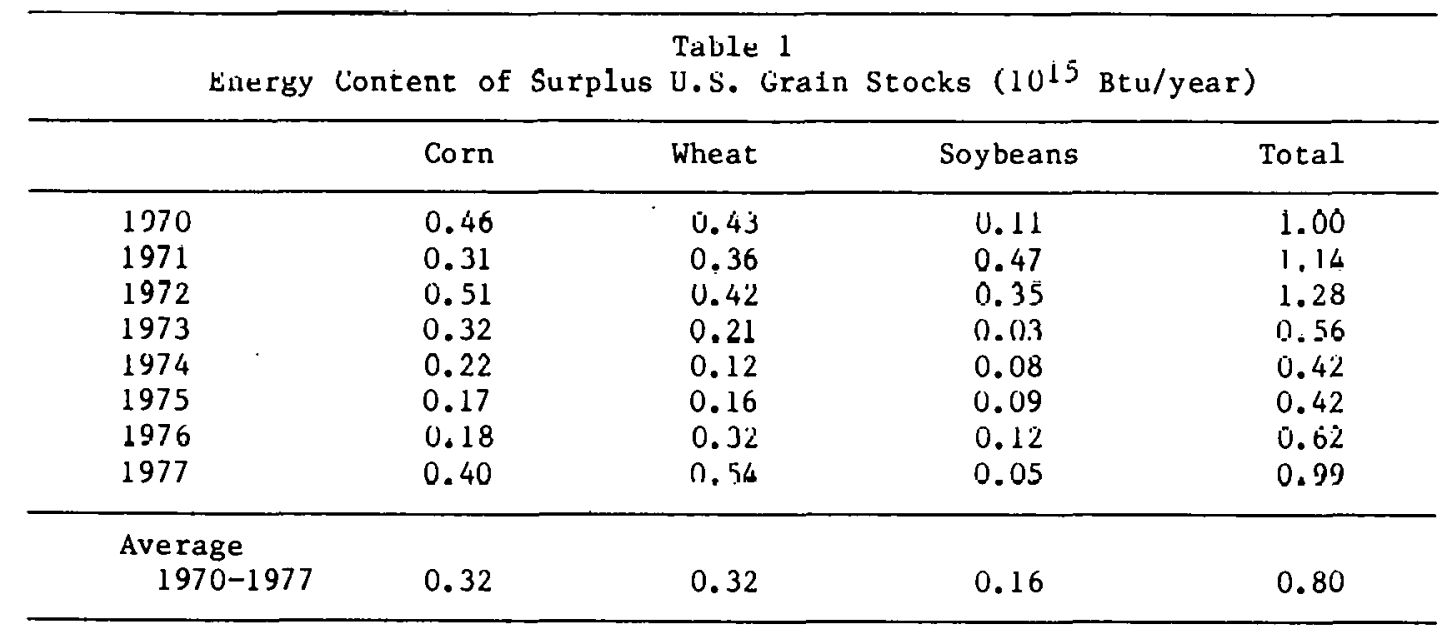

Source: Reference 2

*Carry-over stocks have also been referred to as "surplus stocks."

+ See Appendix for conversion factors used in these and subsequent calculations. 


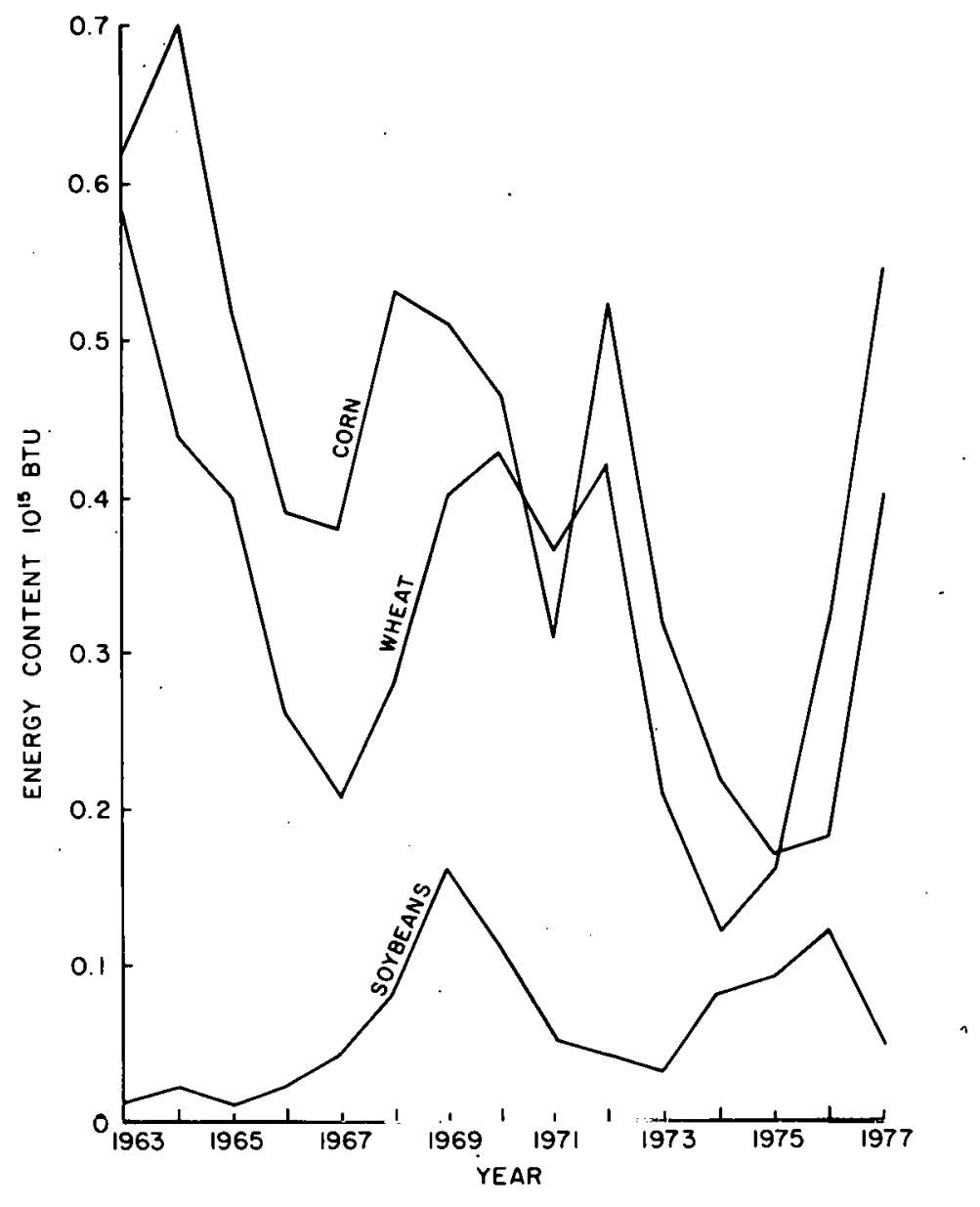

Figure 1. Energy Content of Carry-Over Grain Stocks United States, 1963-77 


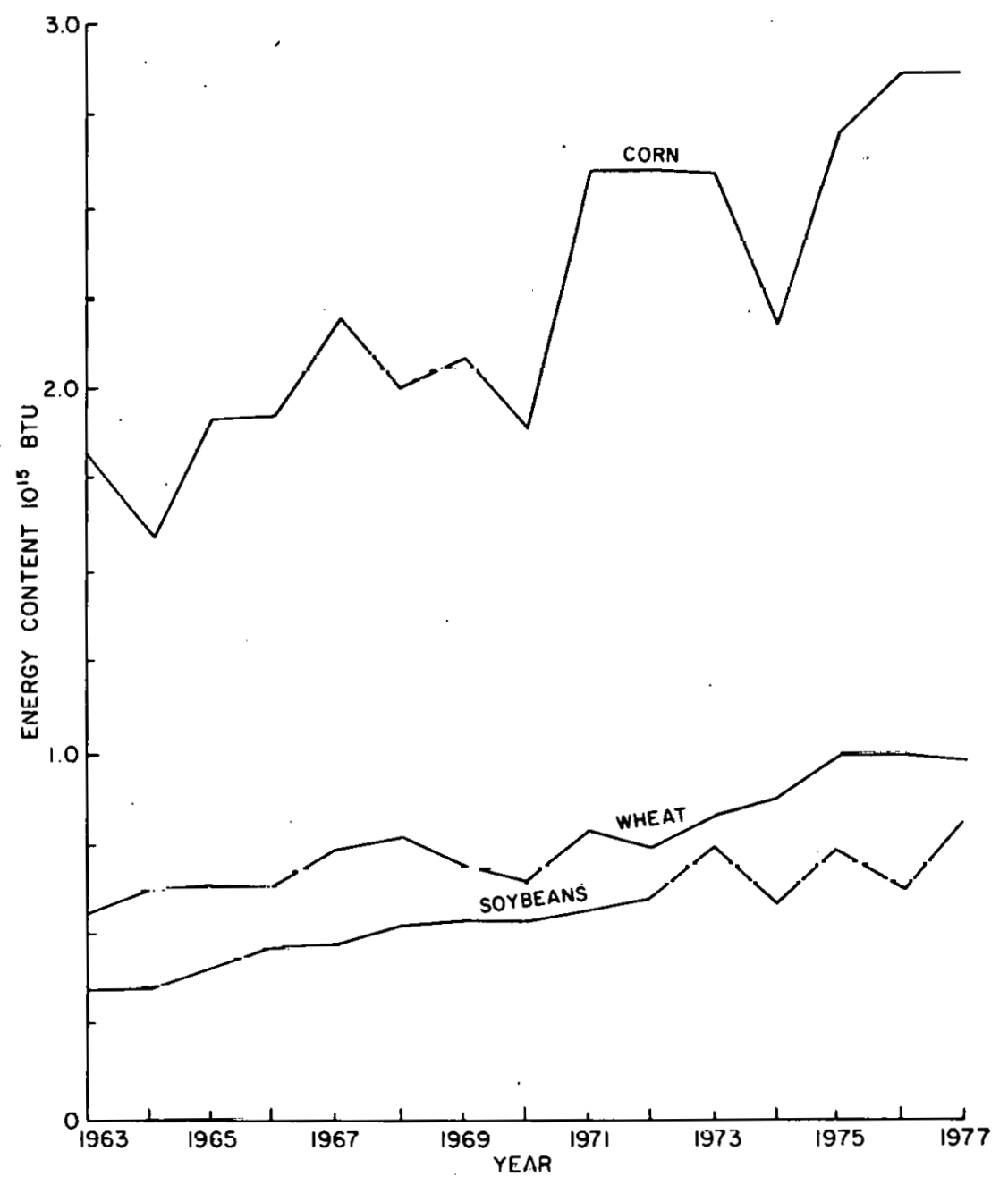

Figure 2. Energy Content of the Total U.S. Production of Corn, Soybeans, and Wheat, 1963-77 
policies have changed and as export demand has increased. Carryover stocks are the small difference between production and consumption plus exports; hence, their level can fluctuate dramatically with small changes in these quantities.

The ratio of the energy content of the carry-over stocks to the annual consumption of coal for power generation in a given year places an upper bound on the extent to which carry-over stocks could substitute for coal. Using the eight-year average for the carry-over stocks of the three grains as a basis for comparison, we find that the energy content of the stocks is about $7 \%$ of the 10.7 quads of coal used for electric power generation in the U.S. in 1977.* If all these stocks were used to displace coal, coal power plants would have an additional 27 day supply of fuel available. Using the largest quantity of stocks for any one of the past 15 years (about 1.3 quads of the three grains), the carry-over stocks could displace approximately $10 \%$ of the coal used in power plants in 1977, equivalent to a coal supply extension of about 40 days. Consequently, from a national perspective, grain could substitute for coal on a limited basis during emergencies; in a prolonged emergency, carry-over stocks, if employed, would soon be depleted.

\section{REGIONAL DISTRIBUTION OF CARRY-OVER STOCKS AND COAL USE}

Although nationally aggregated statistics indicate that carry-over stocks could be important during limited disruptions of coal supply, stocks may not be located in areas with a need for a substitute fuel. To investigate this, a state-by-state analysis was conducted of the availability of carry-over stocks and the use of coal for power generation on the basis of statistics for 1977 . It should be remembered that carry-over stocks and their state by state distributions will vary from year to year. Nonetheless, the general features of the regional distributions of the stocks and of coal consumption will not change significantly in the near future.

Most of the grain produced in the United States is produced in a 16 state region in the Midwestern and North Central portion of the country. Washington is the only other state with a comparable level of grain production. Production is concentrated in seven states--Iowa, Kansas, Indiana, Nebraska, Illinois, Ohio, Minnesota--which alone account for two-thirds of all of corn, soybeans and wheat grown in the United States. Approximately $40 \%$ of the coal used for power generation in the U.S. is consumed in the contiguous 16 grain producing states and Arkansas.

A useful concept which we introduce to aid in understanding the potential of grain stocks as an emergency energy supply is the displacement potential which is defined as the number of days of average coal consumption in a region for which the stocks available in that region could substitute. This assumes that all. carry-over stocks in a region could be transported to and burned in the coal plants there. Because so little is known regarding the probjems that might be associated with handling and feeding grain in plants using pulverizing equipment, the calculations that follow make the simplifying assumption that grain can be used in all plants.

'The coal used fur puwe generation compriacs $75 \%$ of all coal consumed in the U.S. 
Coal consumption, the energy content of the carry-over stocks, and the displacement potential are shown in Table 2 on a state-by-state basis for the grain belt region and for the state of Washington. The displacement potential for the various states reveals a wide disparity in the capability of individual states to meet emergency needs with grain. In some states--Iowa, Kansas, Montana, Nebraska, Oklahoma, North Dakota, and South Dakota--the displacement potential is much greater than the likely length of an emergency shortage. In other states--notably Arkansas, Michigan, and Ohio--the reverse is true.

Table 2

Coal Displacement Potentlal of Carry-Over Stocks in Major Grain Producing States and Arkansas for 1977

\begin{tabular}{|c|c|c|c|}
\hline State. & $\begin{array}{c}\text { Annual } \\
\cdots \text { Coàl consumption } \\
\left(10^{1} 2 \mathrm{Btu} / \text { year }\right) .\end{array}$ & $\begin{array}{l}\text { Carry-over stocks } \\
\left(10^{12} \mathrm{Btu}\right)\end{array}$ & $\begin{array}{c}\text { Displacement potential* } \\
\text { (No. of days) }\end{array}$ \\
\hline Arkansas & 70 & $-\pi$ & 0 \\
\hline Colorado & $1 / 2$ & 18 & 39 \\
\hline Illinols & 719 & 88 & 45 \\
\hline Indiana & 584 & 30 & 19 \\
\hline Iowa & 157 & 146 & 339 \\
\hline Kansas & 99 & 133 & 492 \\
\hline Michigan & 430 & 13 & .. 11 \\
\hline Minnesota & 281 & 70 & 91 \\
\hline M1ssour1 & 402 & 27 & 24 \\
\hline Montana & 62 & 43 & 251 \\
\hline Nebraska & 58 & 70 & 438 \\
\hline North Dakota & 175 & 95 & 198 \\
\hline Ohio & 1040 & 37 & 13 \\
\hline Oklahound & $=$ & 33 & -- \\
\hline South Dakota & 7 & 18 & 890 \\
\hline Texas & 354 & 38 & 39 \\
\hline Washington & 142 & 24 & 62 \\
\hline Wiscoinstin & 223 & 20 & 32 \\
\hline$\cdot$ & & & \\
\hline Total & 4975 & 904 & \\
\hline
\end{tabular}

* Number of days that coal stocks could be extended by complete utilization of carry-over stocks within state.

Sources: References 2,3

A clearer understanding of the potential dispnsitinn nf striks during emergencies is gained by a state-by-state comparison of the requirements for supplemental energy supplies during hypothetical emergencies with the availability of carry-over stocks. This comparison is shown in Table 3 for three levels of reduction in coal stocks-30-, 60-, and 90-day interruptions of normal coal supply. It is assumed that the supply interruption has a uniform impact on all states. In the grain belt, these hypothetical emergencies reduce coal supplies by 415,830 , and 1244 trillion Btu, respectively. In going from 
a 30 day to a 90 day shortage, a pronounced shift is observed in the balance from a sizable net regional excess of stocks compared to needs for supplemental energy to a sizable deficit. In a 30 day emergency, almost all of the grain belt states can individually satisfy their requirements for supplemental energy with grain and still have ample quantities to ship to other states. In a 90 day emergency, however, only the most rural of grain belt states have excess stocks, and these would supply only about half the needs of the remaining states of the region.

Table 3

Potential Excess or Potential Requirements for Carry-Over Stocks by State During Coal Shortages of Various Severities* (Quantities in table are in $10^{12} \mathrm{Btu}$ )

\begin{tabular}{|c|c|c|c|c|c|c|}
\hline State & $\begin{array}{l}\frac{30 \mathrm{Da}}{\text { Excess }} \\
\text { stocks }\end{array}$ & $\begin{array}{l}\text { shortage } \\
\text { Potential } \\
\text { "imports" }\end{array}$ & $\begin{array}{l}\frac{60 \mathrm{Da}}{\text { Excess }} \\
\text { stocks }\end{array}$ & $\begin{array}{l}\text { shortage } \\
\text { Potential } \\
\text { "imports" }\end{array}$ & $\begin{array}{l}\frac{90 \mathrm{Da}}{\text { Excess }} \\
\text { stocks }\end{array}$ & $\begin{array}{l}\text { shortage } \\
\text { Potential } \\
\text { "imports" }\end{array}$ \\
\hline $\begin{array}{l}\text { Arkansas } \\
\text { Colorado } \\
\text { Illinols } \\
\text { Indiana } \\
\text { Iowa } \\
\text { Kansas } \\
\text { Michigan } \\
\text { Minnesota } \\
\text { Missouri } \\
\text { Montana } \\
\text { Nebraska } \\
\text { North Dakota } \\
\text { Ohio } \\
\text { Oklahoma } \\
\text { South Dakota } \\
\text { Texas } \\
\text { Washington } \\
\text { Wisconsin } \\
\text { Totals }\end{array}$ & $\begin{array}{r}4 \\
29 \\
133 \\
124 \\
46 \\
\\
37 \\
65 \\
80 \\
\\
33 \\
17 \\
8 \\
12 \\
2 \\
590\end{array}$ & $\begin{array}{r}22 \\
6 \\
48\end{array}$ & $\begin{array}{r}120 \\
116 \\
23 \\
\\
33 \\
60 \\
66 \\
\\
33 \\
17 \\
\\
1\end{array}$ & $\begin{array}{r}58 \\
39 \\
134 \\
20 \\
16 \\
384\end{array}$ & $\begin{array}{r}107 \\
109 \\
1 \\
28 \\
56 \\
52 \\
33 \\
16 \\
\\
\\
\\
\\
372\end{array}$ & $\begin{array}{r}49 \\
11 \\
34 \\
722\end{array}$ \\
\hline
\end{tabular}

Note: . Excepss Ștocks" = Carry-over stocks above those required to counter the coal shortage within the state.

"Potential Imports" = Difference between reduction in coal supply and energy content of carry-over stocks in a state; this represents the quantity of stocks that could

*Based on 1977 data be imported from other states.

The most effective use of carry-over stocks during an emergency requires transportion of grain from states having large excess stocks to those that consume large amounts of coal. A simple geographic analysis with some consideration given to rail transport routes suggests that the most logical shifts during a 60 day nominal emergency would be as shown in the following table. 
Possible Movements of Stocks During a 60 Day Emergency

[Quantities in parentheses are the excesses(t) or deficits(-) of grain in $10^{12}$ Btu]

$\frac{\text { From }}{\text { Oklahoma }}$
Minnesota
Iowa, Kansas,
Nebraska

Nebraska
$(+296)$

\author{
To \\ Texas, Arkansas - $(-31)$ \\ Wisconsin $(-16)$ \\ Missour1, Illinois, \\ Indiana, Michigan, \\ Ohio
}

Some of these shipmenţ--i.e., from Kansas and Nebraska to Indtana, Michigan, and ohio--require grain transport over distances of 300 to 700 miles, involving substantial costs and complications. Shlpments from North Dakota and Montana would be very expensive because the transporation distances would be roughly 800-1000 miles and so are not included. If the above shifts were actually accomplished, then a total of $791 \times 10^{12}$ Btu of grain would be consumed (including grain used within states) which would replace $95 \%$ of the region's coal supply lost because of the emergency.

COST OF ENERGY FROM CARRY-OVER STOCKS

Carry-over grain stocks are an expensive substitute for coal. Farmer's prices for corn and wheat in 1977 expressed on an energy basis were over $\$ 5.00 / 10^{6}$ Btu and soybean prices were nearly $\$ 14.00 / 10^{6} \mathrm{Btu}$. To these prices must be added transporation costs, estimated to be roughly $\$ 0.50$ to $\$ 1.00$ per $10^{6}$ Btu depending on distance (see Tables 4 and 5). Thus the lowest likely cost for carry-over stocks delivered to a plant is in the neighborhood of $\$ 6.00 / 10^{6}$ Btu. These prices are much higher than the price of coal; the current average price paid for coal used for power generation in the U.S. is about \$1.20. In addition, as Table 6 shows, the prices for corn and wheat were lower in 1977 than they had been for the preceding five years. In fact, if inflation is taken into account for, the 1977 prices were at or near the 15 year historic low point. Thus higher prices should be assumed in assessing the expected future economics of carry-over stocks as an energy source.

The primary alternative to the use of grain during cual shortages is increased generation from nuclear and oil fired units to the extent that spare capacity in such plants permits. Since the variable costs of nuclear power generation are low, nuclear plants are generally used to the maximum extent possible; spare capacity, if it is available at all, is most likely to be found in high variable-cost oil plants. The cost of oil for such plants is about $\$ 3.00$ to $4.00 / 10^{6}$ Btu. The contribution of the oil cost to the cost of electricity will vary depending on the type of oil power plant. For large steam plants, the oil cost is approximately $3 \notin / \mathrm{kWh}$, while for the smaller turbine units, the cost can be up to $6 \notin / \mathrm{kWh}$. The $\$ 6.00 / 10^{6} \mathrm{Btu}$ quoted above as the lowest cost that can realistically be expected for delivered grain is also equivalent to $6 \notin / \mathrm{kWh}$. Hence, although electricity generated from carry-over stocks would be substantially more expensive than that from coal, it may not be much more expensive than electricity from one likely alternative--oil-burning combustion turbines. 


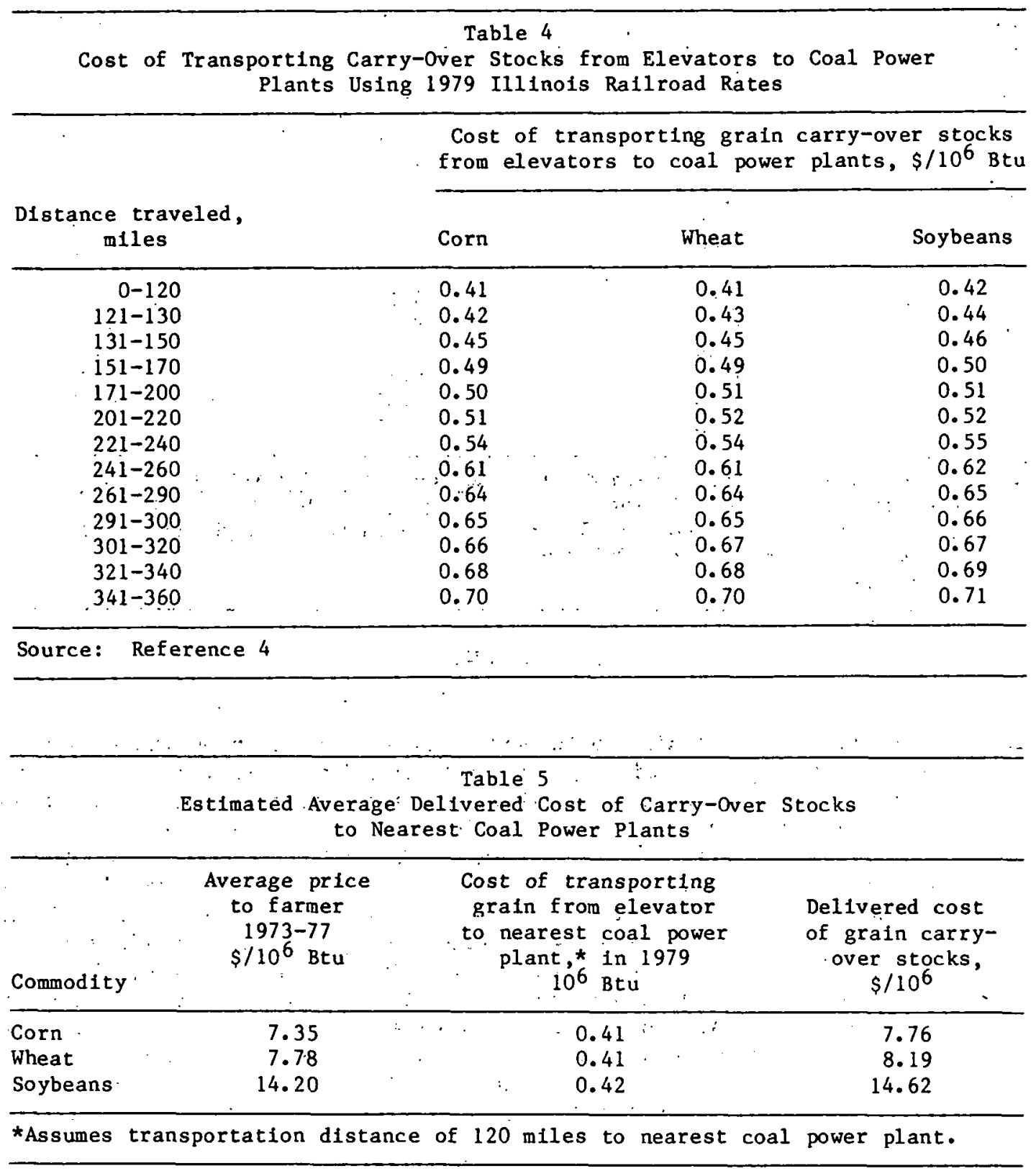




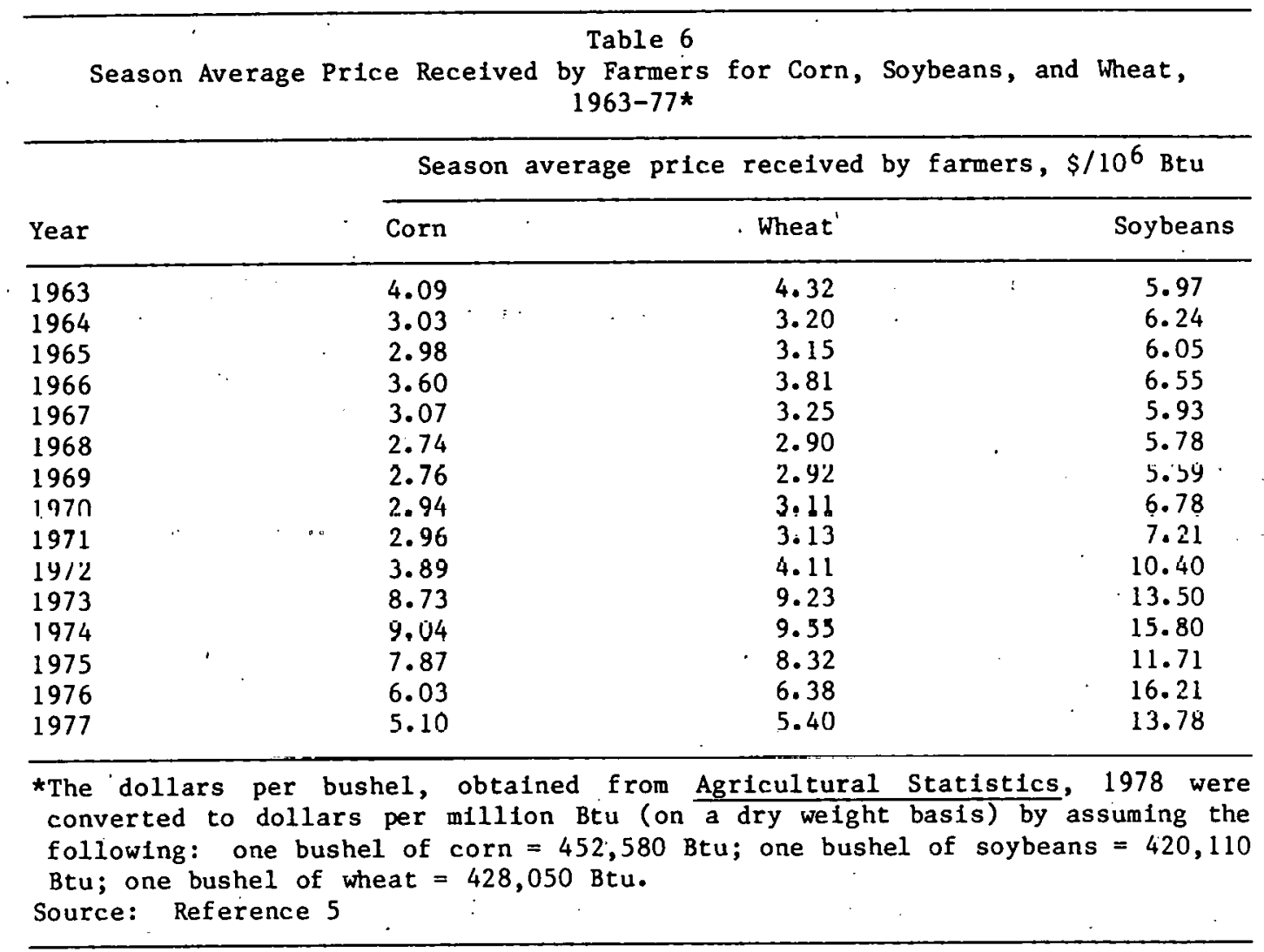

\section{CONCLUSIONS}

Carry-over stocks of grain could serve as a partial substitute for coal during a coal emergency. Their use in $1: 4$ grain-towcoal mixtures in coal plants with crushing equipment has already been demonstrated. Carry-over stocks of corn, soybeans, and wheat available in 1977 had an energy content of 0.8 quad, equal to $7 \%$ of the energy in the coal used for power generation in the U.S. that year. During a nominal 60-day reduction in coal supplies, there would be sufficient stocks to substitute for the reduced supplies of coal burned for power generation to states in the U.S. grain belt which use about $40 \%$ of all coal combusted for power generation in the U.S. Hence, the stocks represent a sizable emergency energy, reserve. In a 60 day national emergency, about half the avallable stocks could be employed for power generation in the state in which they are stored, and the other half could be transported to other states. In some cases transportation of 400 to 700 miles would be required to get the stocks to states, where the need for replacement fuel is needed. 
Carry-over stocks would be an expensive source of energy; corn and wheat prices in 1977, near 15 year lows, were equivalent to over $\$ 5.00 / 10^{6}$ Btu and soybean prices were much higher. These prices are high compared with coal prices which are currently about $\$ 1.20 / 10^{6} \mathrm{Btu}$. Transportation costs estimated to be $\$ 0.50$ to $\$ 1.00$ must be added to the grain price, yielding the delivered costs, at a power plant, of about $\$ 6.00 / 10^{6}$ Btu. The costs of alternatives could be as high as this; the total variable cost of combustion turbine power plants burning distillate fuels is about the same per unit of electricity produced as the delivered cost of the carry-over stocks.

Since carry-over stocks are highly variable from year to year in both price and quantity, their availability cannot be relied upon unless government agricultural policies are changed to encourage the creation of a permanent stockpile.

Important questions remain to be answered before the potential of carryover stocks as an emergency fuel is fully understood. The ability of different types of fuel-feeding equipment to handle grain must be investigated, and the handling and combustion properties of different ratio's of grain/coal mixtures should be further studied. The alternatives to. the use of carry-over stocks must be defined and their costs assessed in order to provide a more detailed and realistic comparison of options. The impact of a sudden, large demand on the price of grain and on the stability of the grain market should also be studied. Finally, the impact of current and prospective government agricultural policies on the price and availability of grain must be included in a more complete assessment: 
Carry-over stocks would be an expensive source of energy; corn and wheat prices in 1977, near 15 year lows, were equivalent to over $\$ 5.00 / 10^{6} \mathrm{Btu}$ and soybean prices were much higher. These prices are high compared with coal prices which are currently about $\$ 1.20 / 10^{6} \mathrm{Btu}$. Transportation costs estimated to be $\$ 0.50$ to $\$ 1.00$ must be added to the grain price, yielding the delivered costs, at a power plant, of about $\$ 6.00 / 10^{6} \mathrm{Btu}$. The costs of alternatives could be as high as this; the total variable cost of combustion turbine power plants burning distillate fuels is about the same per unit of electricity produced as the delivered cost of the carry-over stocks.

Since carry-over stocks are highly variable from year to year in both price and quantity, their availability cannot be relied upon unless government agricultural policies are changed to encourage the creation of a permanent stockp1le.

Important questions remain to be answered before the potential of carryover stocks as an emergency fuel is fully understood. The ability of different: types of fuel-feeding equiptment to handle grain must be investigated, and the handling and combustion properties of different ratios of grain/coal mixtures. should be further studied. The alternatives to the use of carry-over stocks must be defined and their costs assessed in order to provide a more detailed and realistic comparison of options. The impact of a sudden, large demand on the price of grain and on the stability of the grain market should also be studied. Finally, the impact of current and prospective government agricultural policies on the price and availability of grain must be included in a more complete assessment.

APPENDIX

\begin{tabular}{lcccc}
\hline \multicolumn{5}{c}{ Average Energy Values } \\
\hline Crop & 1b/bushel & \% moisture & Dry $1 \mathrm{~b} /$ bushel & Btu/dry 1b \\
\hline Corn & 56 & 15.5 & 47.3 & 8170 \\
Wheat & 60 & 12.0 & 52.8 & 8107 \\
Soybeans & 60 & 12.5 & 52.5 & 8001 \\
Coal & & & & 11,200 \\
\hline
\end{tabular}

Sources: References $5,6,7,8$. 
1. *Personal communication, Edwin A. McDivitt, Logansport Indiana Electric Department, Logansport, Indiana 46947.

2. United States Department of Agriculture, Statistical Reporting Service, Stocks of Grains, Oilseeds and Hay, by States, Annual reports 1970-1977.

3. Edison Electric Institute, Statistical Year Book of the Electric Utility Industry, p.33, New York, October 1978.

4. Personnel communication; Mr. Len Bruder, Illinois Central Gulf Railroad, Chicago, Illinois, February 1979.

5. United Stated Department of Agriculture, Statistical Reporting Service, Agricultural Statistics, 1976. For 1977, 78 personal communiction; John Gerald, United States Department of Agriculture.

6. Miller, D.F., Composition of Cereal Grain and Forages, Publication 585, Nat. Acad. Sci., Nat. Res. Counc., pp. 495-505, 1958.

7. Illinois Department of Business and Economic Development, Agricultural Energy Requirements and Land Use Patterns in Illinois, Illinois Division of Energy, Springfield, Illinois, August 1976.

8. Personal communication; William Dowdy, United States Department of Agriculture. 